\title{
Corporate Attributes Influencing the Compliance of Islamic Finance: Evidence from Listed Companies under Shariah Index in India
}

\author{
Kamrunnisha Nobi1, Manjit Singh ${ }^{2}$ (D), Arun Aggarwal ${ }^{3 *}$ (1) \\ ${ }^{1}$ Mata Ganga Khalsa College for Girls, Panjab University, Chandigarh, India \\ ${ }^{2}$ Punjabi University, Punjab, India \\ ${ }^{3}$ Chitkara Business School, Chitkara University, Punjab, India \\ Email: *arunaggarwal.mba@gmail.com
}

How to cite this paper: Nobi, K., Singh, M. and Aggarwal, A. (2019) Corporate Attributes Influencing the Compliance of Islamic Finance: Evidence from Listed Companies under Shariah Index in India. Theoretical Economics Letters, 9, 1744-1771. https://doi.org/10.4236/tel.2019.96112

Received: March 4, 2019

Accepted: August 4, 2019

Published: August 7, 2019

Copyright ( 2019 by author(s) and Scientific Research Publishing Inc. This work is licensed under the Creative Commons Attribution International License (CC BY 4.0).

http://creativecommons.org/licenses/by/4.0/

(c) (i) Open Access

\begin{abstract}
The aim of this paper is to provide empirical evidence relating to the factors influencing the compliance of Islamic finance by Indian corporate sector. The sample comprised of the whole population of Shariah companies numbered as 190 consisted in the 500 Shariah and Nifty Shariah indices during the period of 2009 till 2014. However, after making the necessary filtration due to unavailability of data, the actual size of the sample came out to be $136 \mathrm{com}$ panies. The relationship between factors and the extent of compliance were analysed using Panel data regression model. The results evident that companies of larger size and higher growth rate have significant mandatory compliance. Whereas, firm size examined with net sales and board independence has withstood with compliance of voluntary and overall measures. The significant implication of our results is that it provided information on firm specific characteristics for the investors who are looking for investment in Shariah compliant companies. In this way investor would be able to keep an eye on their investment. These results may also be advantageous to the regulators in making decisions. Distinct from previous empirical research concerning to Islamic social reporting in Muslim and non-Muslim countries, this study examines the factors affecting the extent of Shariah compliance by the companies listed under Shariah Index in Indian stock exchange.
\end{abstract}

\section{Keywords}

Shariah, Random Effect, Compliance, Panel Data Analysis 


\section{Introduction}

Shariah screening process is comparatively a new entrant in the Islamic finance domain [1] [2]. Muslim community was usually disinclined to participate in stock market just before 1970s owing to the fact of instant Shariah forbiddance enforced on capital market [3]. However, religious rein took a quantum leap during 1990s relating to investment in equity and permitted Muslim to be involved in stock market enforcing certain stipulation [4]. To be mindful of the present market scenario and the contribution of the listed companies in an economic system, a group of dominant Shariah scholars had come about and accorded certain criteria in the course of time 1987 to make Muslim investors able to possess, hold up and transact the shares of the listed companies [5]. It is one of the major initiatives towards encouraging the development of Islamic capital market. Since it provides avenue to Muslim investors and enables them to partake in financial market [6] [7]. Islamic capital market also serve the purpose of Shariah compliant investment for Islamic banking and insurance industry, hence, reckoned as a backbone of whole Islamic financial system [8] [9]. A credence over this market has been shown by investors considering the prominent feature of financial investment which should be in harmony with the Islamic principles [10]. Shariah screening of the portfolio is being performed to ascertain whether these are in conformation with the preconditions laid down by the Shariah board [11] [12]. It is incumbent on screening authority to filter out the business transactions in accordance to Islamic stock screening methodology [13] [14]. In view of the fact that experienced Muslim investors are increasing in the global financial market and they anticipate their funds to be well managed which is aligned according to Islamic values and principles [15]. Shariah screening standards forbids companies from not to indulge much in lending and highly levered activities that in consequence improves the performance of Shariah compliant companies [16]. Given that, Shariah compliant companies provides higher return as compared to non-Shariah and showcased better performance during the period of turmoil [17]. Owing to this reason, this study will concentrate on the relationship between the factors selected on the basis of prior literature and Shariah compliance of the companies. The present study aims to examine the factors influencing the compliance (i.e. mandatory, voluntary and overall compliance of the parameters) of Islamic finance by Indian corporate sector. The extent of compliance of Shariah principles vary from one company to another company however, the firm-specific attributes tend to influence Shariah compliance by the companies. This study analysed the relationship between the extents of compliance and corporate attributes of Shariah compliant companies. Although there are several studies that have investigated the factors that may influence a company to provide corporate social reporting and negligible number of studies on Islamic social reporting but none of the studies to the best of my knowledge have analysed Shariah compliance by the companies in India. The firm-specific characteristics whose impact on extent of Shariah com- 
pliance are inquired in this study such as Net sales, Total assets, Market capitalisation, return on Assets, return on capital employed, return on net worth, Growth, Leverage, Age of incorporation, Board size, Board independence and Nature of industry. The significance of hypothesising and testing empirically for the impact of these firm-specific characteristics on Shariah compliance practices of the listed companies under Shariah Index is to recommend areas where efforts to improve the Shariah compliance regulating authorities in the country should be focussed. The study of the firm specific characteristic was pioneered by [18], which ascertained the extent of disclosure. It is considered to be important or desirable to measure disclosure by an index of 31 information items by financial analysts in their investment decision making and also reasoned to improve the financial reporting practices of many US companies. The corporate-specific attributes comprises of number of shareholders, asset size and profitability had been noticed to cause the differences in disclosure [18]. The several researchers have adopted [18] study and duplicated his methodology with or without some changes (see. [19]-[26]). Therefore, an attempt has been made by extending this area of study to companies comprised under Shariah index listed on the NSE India.

Although there are myriad studies examining the conventional social reporting followed by voluntary disclosures made by the companies available in abundance in the national and international sphere. Succeeded by, very few of the studies with respect to Islamic social reporting and the Shariah compliance of the companies are found in the international arena, however, to the best of my knowledge, the level of compliance of Shariah principles made by the companies under different industries has been overlooked yet in India. One of the important issue that has been often talked about is the determinants influencing the conventional social reporting, voluntary disclosures and Islamic social reporting. The various firm specific characteristics are recognised in the prior studies which effect conventional social reporting, mandatory and voluntary disclosures and Islamic social reporting but could those factors impact the Shariah compliance of the companies have not been discussed. So, the empirical purpose of this paper is to scrutinize if those factors could influence the extent of Shariah compliance or not.

The paper is organised as follows. The second section briefly discusses the theoretical background of various determinants and help to develop the hypothesis. The third section explores the econometric model with special reference to Panel regression to consider both the dimension time and cross-section of the data. The fourth section reports the results of empirical analysis. The fifth section talks about concluding remarks which contains implication and future scope of the study.

\section{Theoretical Background and Development of Hypotheses}

In this section, researchers explained different independent variables and how these variables are related to dependent variable (Disclosure of Shariah 
compliance).

\subsection{Dependent Variable}

Disclosure of Shariah compliance index is the dependent variable. The study employed content analysis tool to examine the extent of Shariah compliance by the different companies that have been a generally acceptable method of coding used in the prior studies of disclosure [27] [28] [29] [30]. An index was formulated consisting of 47 items and further sub-categorised into 6 themes. A number of items related to Shariah compliance are there in each theme. This method was adopted in various studies, however, concerning to Islamic social reporting put forward by [27] [31] and CSR information disclosure for Islamic financial institutions [27] [31] [32] but no study to the best of knowledge in India measured the financial aspect of Shariah compliant companies as recommended by Shariah advisory. Owing to this reason, the study has been extended by developing Shariah compliance index and taking into account the financial parameters along with rest of the five parameters to determine the Shariah compliance of the companies.

\subsection{Independent Variable}

This study considered several factors that could contribute to the extent of Shariah compliance by the different companies based on prior studies have been discussed below. Results of the previous studies revealed that firm size, profitability, board composition, leverage, nature of the industry, age along with increase in independent directors influenced the extent of Islamic social reporting and voluntary disclosure [33]-[43].

\subsubsection{Size}

Company size would influence the decision-making of the company while disclosing the information in the annual report [44]. It is used to assess the political cost which increases as per the size of company and the level of risk [45]. It is concerned with agency theory in which larger firm bearing high agency cost would dig into for more information in order to cut down the agency costs [41] [43] [46]. The various aspects of the company are generally explained by company size which is considered as an estimator variable. Company size can be ascertained on the basis of the total assets, size of equity together with company value [47]. Size constitutes as one of the most important variables in ascertaining the extent of disclosure. The relationship between size and voluntary disclosure in general had been examined in a lot of studies [36] [48]-[53]. The impact of size on disclosure has been examined all around the different countries such as the Austria [54], US [25] [26] [55], Canada [56], the UK [24], Mexico [57], Nigeria [23], Spain [20] [58] and Sweden [22]. On the basis of above discussion the following hypothesis is evaluated:

$\mathrm{H} 1$ : There is a significant relationship between size of the company and extent of Shariah compliance. 


\subsubsection{Leverage}

The previous studies ascertained relationship between financial leverage and the extent of disclosure [59]. It is indicated by [60] that decrease in debt holder's inclinations to price-protect in contrast to transfers from themselves to shareholder has been observed with the increase in disclosure on the basis of agency theory. In various studies, a positive relationship between leverage and corporate disclosure has been determined [61]. According to [62], more highly leveraged firms attempt to disclose more information in annual reports in order to cut down monitoring costs incurred by the companies. On the other hand, [63] established a negative and significant relationship between leverage and the corporate social responsibility. It is indicated that the firm with high leverage in order to fend off creditor scrutiny will bring down its CSR communication. The high leverage company seeks not to get much attention from the debt holders by reducing the corporate governance disclosure. [42] found a significantly negative effect of leverage on corporate social responsibility disclosure while examining the factors influencing disclosure of CSR in Indonesia. The prior study demonstrated that size control variable and leverage leads to good corporate governance which results in a good impact on the value of company [64]. In view of above discussion, the following hypothesis is assessed:

$\mathrm{H2}$ : There is a significant relationship between leverage of the company and extent of Shariah compliance.

\subsubsection{Growth}

It is anticipated that companies with the higher growth opportunities incline to make effort on improving the disclosure level [65]. The prior studies used growth as a predictor variable to test the difference in disclosures of companies. However, the compliance of Shariah principles could get influenced by the growth of the company should also be examined. In the view of above discussion, the following hypothesis is examined:

H3: There is a significant relationship between growth of the company and extent of Shariah compliance.

\subsubsection{Profitability}

The prior studies make it evident that profitability has the capability of affecting the extent to which companies reveal mandatory information in the annual reports [18] [26] [34] [66] [67]. To support this assumption, various reasons have been put forward. Profitability is considered as a standard of management performance and so the profitable organisation is expected more to reveal to help the users in making financial decisions and explaining their compensation package and position [26] [68]. Otherwise, organisation with a poor performance may reveal less information to hide the unsatisfactory position. In some studies [69], the direction of relationship between profitability and disclosure is not clear however, [20] established no association between profitability and disclosure. Nevertheless, profitable company is more possibly to divulge information required by the users. In view of 
above discussion, the following hypothesis is studied:

H4: There is a significant relationship between profitability of the company and extent of Shariah compliance.

\subsubsection{Age}

Empirical evidence with regard to company age and voluntary disclosure found an association between them [36] [37]. Moreover, long established firm are more inclined towards communicating voluntary social disclosure reported by prior research that debated the age of the company and its influence on CSR (corporate social responsibility) participation. [70] indicated positive association between CSR and age of firms. The reason behind this association is that deep-rooted firms have acquired more assistance from the society as compared to young companies and over the period of time as the relationship grows older company attempts to take a greater leadership role and develop the sense of social responsibility. [71] observed that deep-rooted firms dispose to communicate more information than budding companies. On the basis of above discussion, the following hypothesis is investigated:

H5: There is a significant relationship between age of the company and extent of Shariah compliance.

\subsubsection{Board Size}

Board size can influence the extent of disclosure, controlling and monitoring process indicated by various empirical studies in corporate governance [40] [72]. Large board size makes the task of controlling CEO and monitoring process uncomplicated and effective [73]. On the other hand, communication and coordination amongst board members could be restrained due to very large board size and therefore will prevent process of monitoring. It is necessary to maintain an appropriate size of board as very large or small board will not be efficacious and suggests non-linear relationship between size of board and corporate social responsibility, where evidence of positive effect on CSR with larger board size and negative influence with a very large board size is found. In the opinion of [74], a large board size may wane the possibleness of information asymmetry. In addition to that, it may also bring down the precariousness and the dearth of information [75]. Given the more members on the board, the capability of members of the SSB to oversee the functions of bank that influence the welfare of the society becomes much higher. Since, collaborative knowledge and acquaintance of the SSB members will develop with the more members that contribute towards higher communication of CSR information. The following hypothesis is tested, on the basis of above discussion.

H6: There is a significant relationship between board size of the company and extent of Shariah compliance.

\subsubsection{Board Independence}

It is considered that many of the corporate governance problems can be solved with the presence of Independent directors on the board of the company. Inde- 
pendent directors on the board performed an oversight role on management on shareholder's part and also believed to be as a potential solution to the problems. They can supervise management efficaciously as per the assumed facts because they do not require a disposition to good graces of management, and can express their opinion openly and without any hesitation or fear in front of management misdeeds, outside and inside the boardroom, with the objective of shielding the interests of shareholders [38]. It is examined that the composition of independent commission board and corporate social responsibility disclosure of the company are positively and significantly correlated with each other [76]. An empiric manifestation with respect to independent director's role towards corporate transparency is found to be mixed regardless of witnessing its so many utility. [39] evidenced the role of independent directors in holding back the earnings management efficaciously between the Standard and Poor's 100 firms in the United States. [77] demonstrated that the independent directors encourage voluntary disclosure amongst Italian companies accompanying prevalent shareholders. [78] indicated higher extent of voluntary disclosure in Singapore if the firm having majority of independent directors or a higher proportion of independent directors on the board. But then, [36] [79] observed no significant relationship between independent directors and the level of voluntary disclosure in Hong Kong and Malaysia, respectively. Given the foregoing discussion, following hypothesis is submitted:

H7: There is a significant relationship between board independence of the company and extent of Shariah compliance.

\subsubsection{Nature of Industry}

The study included industry type as a predictor variable. It is argued that the disclosure practices of the firm are not expected to be same across varied industry due to the variations may occur in accounting policies and practices of the companies [35] [80]. The reason behind differences could be a particular situation in which specific industry might come across and affect their disclosure practice [20]. The overall contributions of certain industries towards export earnings or national income of the country become the reason for its rigorous control and high regulation. This may also influence the disclosure and reporting practices of the firm in that specific industry [35]. The other studies [81] suggested, for instance, companies under media industry are less expected to disclose certain accounting ratios as compared to companies in the other industries. Because the feeling of making less additional disclosures comes among the companies under the regulated industries in order to make their activities legal. [82] suggested that import of intermediate materials and foreign partnership influence the performance of the firms. [52] indicated the bandwagon effect according to that if one company prevalent in the industry disclose more, this would prompt other companies to disclose more belong to the same industry. The findings of prior studies showed mixed results. [83] suggested a positive relationship between types of industry and the level of corporate disclosure 
whereas, [20] [35] suggested no significant relationship between industry type and level of corporate disclosure. Therefore, foregoing discussion contributed to the development of the following hypothesis:

H8: There is a significant relationship between nature of industry of the company and extent of Shariah compliance.

\section{Econometric Model}

A panel data regression model has been employed to study the factors that could influence the Shariah compliance of the companies. This model has been preferred over the multiple regressions because it can handle the datasets containing both cross-sections and time period observations. A panel data regression can be measured with the help of Fixed Effect Model (FEM) or Random effect model (REM). But this study rests on REM model due to the inclusion of some sector specific dummy variables and precluded the application of FEM model. Here is the glimpse of a panel data regression model below:

\subsection{Panel Data}

Panel data analysis examines the particular subject within multiple sites over a specified time form which has been observed periodically. However, combining the cross-sections with time series can make the quantity and quality of data better in the way that it would be inconceivable to employ only one of these attributes [84]. It is considered to be a powerful and rich tool for the one who takes into account both the dimensions time and cross-section of the data. Panel data analysis by considering both a temporal and spatial aspects empowers the regression analysis. A set of cross-sectional units of observations are known as the spatial dimensions which could be firms, states, commodities, countries, group of people, or even individuals. Whereas, periodic observations of a group of variables are regarded as a temporal dimension. There are various kinds of analytical models to study the panel data such as Pooled regression model (the constant Coefficients Model), Fixed effects model (Least Square Dummy Variable Model), Random effects model, Dynamic panel, Robust models and covariance structure models.

There are three competing formulations according to Table 1. The first is to ignore the panel nature of the data and treat the disturbance term as identically and independently distributed. The disturbance is uncorrelated with the explanatory variables. In this case data can be pooled and ordinary least squares (OLS) can be used to estimate the model, as the selection of any technique depends on the underlying objectives and the meeting of the assumption of that technique. In the current case there is no theoretical foundation supporting the application of GMM or FMOLS. Also, the dataset being investigated does not fulfill all the assumptions of these techniques. Hence, OLS regression technique has been deployed. We call this the pooled model. Pooled regression model is also recognised as the constant coefficients model. This model has 
Table 1. Panel data models.

\begin{tabular}{ccc}
\hline MODEL $y_{i t}=\alpha_{i t}+X_{i t}^{\prime} \beta+u_{i t}$ & INTERCEPT TERM & DISTURBANCE TERM \\
\hline Pooled Model & $\alpha_{i t}=\alpha$ & Uit \\
One-Way Fixed Effects & $\alpha_{i t}=\alpha+\mu_{i}$ & Uit \\
Two-Way Fixed Effects & $\alpha_{i t}=\alpha+\mu_{i}+\lambda_{t}$ & Uit \\
One-Way Random Effects & randomly changing over $i$ & $u_{i t}=\mu_{i}+v_{i t}$ \\
Two-Way Random Effects & randomly changing over $i$ & $u_{i t}=\mu_{i}+\lambda_{t}+v_{i t}$
\end{tabular}

constant coefficients and implies to both slopes and intercepts that are neither significant to cross-section nor significant temporal effects rather pool all the data and run an ordinary least squares regression model. The pooled model essentially postulates that both the intercept and the slope coefficients are the same across individual units and time.

\subsection{Generalized Least Squares (GLS)}

In order to apply GLS, we need to calculate $\theta$ by utilizing the $\Omega$ matrix:

$$
\theta=1-\sqrt{\frac{\sigma_{v}^{2}}{T \sigma_{u}^{2}+\sigma_{v}^{2}}}
$$

${ }^{*}$ If $\theta=0$, run pooled OLS regression. If $\theta=1$ and $\sigma_{v}^{2}=0$, then run the within effect model.

In order to run an OLS, we first need to transform the variables as below:

$$
\begin{gathered}
\alpha^{*}=1-\theta \\
x_{i t}^{*}=x_{i t}-\theta \bar{x}_{i} \text { for all } X_{k} \\
y_{i t}^{*}=y_{i t}-\theta \bar{y}_{i}
\end{gathered}
$$

Now, on the transformed variables we can run an OLS.

$$
y_{i t}^{*}=\alpha^{*}+x_{i t}^{* \prime} \beta^{*}+\varepsilon_{i t}^{*}
$$

\subsection{Feasible Generalized Least Squares (FGLS)}

In order to apply FGLS, the first thing is to estimate $\theta$ with the help of $\hat{\sigma}_{v}^{2}$ and $\hat{\sigma}_{u}^{2}$.

$$
\hat{\theta}=1-\sqrt{\frac{\hat{\sigma}_{v}^{2}}{T \hat{\sigma}_{u}^{2}+\hat{\sigma}_{v}^{2}}}=1-\sqrt{\frac{\hat{\sigma}_{v}^{2}}{T \hat{\sigma}_{\text {between }}^{2}}}
$$

The $\hat{\sigma}_{v}^{2}$ comes from sum of squared errors (SSE) of the "within effect estimation" or the deviations of residual from group means of the residuals:

$$
\hat{\sigma}_{v}^{2}=\frac{S S E_{\text {within }}}{n T-n-k}=\frac{e^{\prime} e_{\text {within }}}{n T-n-k}=\frac{\sum_{i=1}^{n} \sum_{t=1}^{T}\left(v_{i t}-\bar{v}_{i}\right)^{2}}{n T-n-k}
$$

where $v_{i t}$ represents the residuals of LSDV. 
The $\hat{\sigma}_{u}^{2}$ is derived from group mean regression (between effect estimation):

$$
\hat{\sigma}_{u}^{2}=\hat{\sigma}_{\text {between }}^{2}-\frac{\hat{\sigma}_{v}^{2}}{T}, \text { where } \hat{\sigma}_{\text {between }}^{2}=\frac{S S E_{\text {between }}}{n-K}
$$

Now, transform the variables by utilizing $\hat{\theta}$ and then we can perform an OLS:

$$
\begin{gathered}
y_{i t}^{*}=\alpha^{*}+x_{i t}^{* \prime} \beta^{*}+\varepsilon_{i t}^{*} \\
\alpha^{*}=1-\hat{\theta} \\
x_{i t}^{*}=x_{i t}-\hat{\theta} \bar{x}_{i} \text { for all } X_{k} \\
y_{i t}^{*}=y_{i t}-\hat{\theta} \bar{y}_{i}
\end{gathered}
$$

A two-way random effect model is when there is within effect error component in both the time series and cross-section in a random effect model. In this situation, the error term should be uncorrelated with both group (cross-sectional) error and time series component. The orthogonality of both the component permits the general error to be decomposed within the cross-sectional temporal, specific and individual error components.

$$
e_{i t}=v_{i}+e_{t}+\eta_{i t}
$$

Here, $e_{t}$ represents the time specific component. This $e_{t}$ is peculiar to all observations for that time period, $t . \quad v_{i}$ represent the cross-section specific error. This component affects only those observations which are in that panel. Whereas, particular observation in the panel is affected by $\eta_{i t}$. These kind of models are referred to as two-way random effects model (SAS, 1999).

\subsection{LM Tests for Random Effects}

Testing for the existence of cross-section (individual) and time effects is important in panel and pool regression settings since accounting for the presence of these effects is necessary for correct specification of the regression and proper inference. Eviews offers testing for individual and time effects using both F-statistic (likelihood ratio) and Lagrange multiplier (LM) tests. The F-statistic test is used in case of fixed effects model whereas, Lagrange multiplier (LM) test is used in case of a random-effects model.

The most popular random effects test is the [85] LM test. [86] derives component LM tests with one-sided alternatives, obtaining a uniformly most powerful (UMP) test statistic. [87] propose a standardized version of the Honda test that has improved asymptotic size. King and Wu (1997) introduce a locally mean most powerful (LMMP) one-sided LM test. In addition, [88] [89] extend the Breusch-Pagan, Honda, and King and Wu approaches to unbalanced designs.

[85] developed LM (Lagrange Multiplier) test in order to test the presence of individual and time effects in the model [90]. The null hypothesis for LM test states that $\sigma_{u}^{2}=0$, that is, the variance components of the cross-section are zero. That is, the null hypothesis of the LM test support for pooled model. Whereas an alternative hypothesis renders that the variance of the individual 
specific term is not equal to zero, that is it holds the random-effects model. The Lagrange Multiplier Test complies chi-square $\left(x^{2}\right)$ distribution with degree of freedom equal to one. If the tabulated value of chi-square is less than that of calculated value, in that case null hypothesis is rejected and we accept alternative hypothesis. Therefore, we can propose that random effects model is more suitable than pooled model (OLS) for that particular data set.

$$
L M_{u}=\frac{n T}{2(T-1)}\left[\frac{e^{\prime} D D e}{e^{\prime} e}-1\right]^{2}=\frac{n T}{2(T-1)}\left[\frac{T^{2} \overrightarrow{e^{\prime}} e^{\prime}}{e^{\prime} e}-1\right]^{2} \sim x^{2}(1)
$$

where, $e^{\prime} e$ represents the Sum of Squares due to Error (SSE) of the pooled model (OLS regression model), and $\bar{e}$ represents the $n \times 1$ vector of the group means of pooled regression residuals.

[91] introduced the same Lagrange Multiplier Test, but in a different form.

$$
L M_{u}=\frac{n T}{2(T-1)}\left[\frac{\sum\left(\sum e_{i t}\right)^{2}}{\sum \sum e_{i t}^{2}}-1\right]^{2}=\frac{n T}{2(T-1)}\left[\frac{\sum\left(T e_{i}\right)^{2}}{\sum \sum e_{i t}^{2}}-1\right]^{2} \sim x^{2}(1)
$$

If we accept the alternative hypothesis then it means that a random effects model is more relevant and efficient in handing the heterogeneity in the model better than a pooled OLS model. In a two-way random effects model, the null hypothesis is $H_{0}: \hat{\sigma}_{u}^{2}=0$ and $\hat{\sigma}_{v}^{2}=0$. In another words, a Lagrange Multiplier (LM) test combines two one-way random effects model for time and group, that is,

$$
L M_{u 12}=L M_{u 1}+L M_{u 2} \sim x^{2}(2) .
$$

\section{Results}

\subsection{Multicollinearity Tests}

When the study includes a number of predictor variables the problem of multicollinearity arises. Consequently, it becomes hard to ascertain the impact of each of the predictor variables on the response variable [92] [93]. When the correlation is found to be greater than 0.80 (Gujarati, 1995), or the variance inflation factor (VIF) transcends ten, then multicollinearity is considered to be a grave problem [94] [95]. Because higher level of VIF could affect the results of regression analysis so researchers want it to be lower. A variance inflation factor suggests the magnitude of the inflation related to a beta weight in the standard errors on account of multicollinearity. In other words, VIF evaluates the increase in variation of a calculated regression coefficient with the correlated predictors. For instance, a factor with a VIF of 7 increases the standard errors than would be the case otherwise, if there were no inter-correlations among the independent variable of interest and rest of the independent variable consists in the regression analysis. The variance inflation factor (VIF) is used as a signal of multicollinearity in multiple regressions. It is determined as the reciprocal of tolerance:

$$
\mathrm{VIF}=\frac{1}{1-R^{2}}
$$


Several authors have been given recommendations for the acceptable extent of VIF. A value of utmost 10 level of VIF has been most commonly recommended [96] [97] [98] [99]. The recommended VIF value of 10 represents as the tolerance recommendation of 0.10 (in other words, $1 / 0.10=10$ ). Nevertheless, a value of maximum 5 VIF [100] and still 4 VIF [101] are supported by previous studies. Therefore, researchers can opt any of the measures which would serve their purpose. The VIF is estimated to examine the multicollinearity problem.

The presence of multicollinearity in the data has been determined by using Variance Inflation Factor (VIF). Table 2 showed the VIF values for all variables. It is observed from the results that there is no problem of multicollinearity between Age of the company, Director, Market capitalisation, Net sales, Leverage, Board Independence, Growth, Return on capital employed, Return on Assets and Total assets. However, there is a multicollinearity problem found in Net Worth. Therefore, Net worth variable was excluded from the regression model. The value of Durbin Watson is between the value of du and 4 -dl $(\mathrm{du}<\mathrm{DW})$.

Table 3 provides the descriptive statistics of all the variables considered for this study. It is observed from Table 3 that means of test variables such as, mandatory, voluntary and overall compliance exhibited about 92.1 percent, 69.8 percent and 71.7 percent for all the companies, respectively. On the other hand, the mean values of predictor variables namely Net sales (9.99), Total Assets (10.26), Market capitalisation (10.88), Return on Assets (0.17), Return on capital employed (19.51), Growth (14.45), Leverage (0.20), Age (3.49), Board Size (2.33) and Board Independence (0.43). For measuring the normality of the data, skewness and kurtosis have been used. In the current study, the skewness values range

Table 2. Multicollinearity test.

\begin{tabular}{cccc}
\hline Variable & Coefficient Variance & Uncentered VIF & Centered VIF \\
\hline C & 16.68750 & 135.2439 & NA \\
Board Independence & 8.102560 & 13.40537 & 1.033642 \\
Growth & 0.000647 & 2.231818 & 1.136202 \\
Leverage & 1.699194 & 1.875145 & 1.269834 \\
Age & 0.366728 & 37.38866 & 1.096212 \\
Director & 2.294798 & 102.5220 & 1.409567 \\
Market Capitalisation & 0.297428 & 291.9034 & 6.401163 \\
Net Sales & 0.213391 & 177.0659 & 4.241955 \\
Total Assets & 0.530402 & 462.3138 & 9.535807 \\
Return on Capital Employed & 0.002373 & 11.45850 & 4.132267 \\
Return on Assets & 51.42381 & 16.64003 & 3.908662 \\
\hline
\end{tabular}

Source: Compiled by Author. 
Table 3. Descriptive statistics.

\begin{tabular}{cccccccc}
\hline Variables & Mean & Median & Max & Min & S.D & Skewness & Kurtosis \\
\hline Mandatory Compliance & 92.15 & 100.00 & 100.00 & 50.00 & 12.92 & -1.35 & 3.83 \\
Voluntary Compliance & 69.77 & 70.00 & 84.00 & 49.00 & 5.63 & -0.25 & 2.88 \\
Overall Compliance & 71.71 & 72.00 & 85.00 & 51.00 & 5.30 & -0.17 & 2.92 \\
Net sales & 9.99 & 9.91 & 15.20 & 2.82 & 1.56 & -0.02 & 4.44 \\
Total Assets & 10.26 & 10.02 & 15.11 & 7.04 & 1.49 & 0.67 & 3.23 \\
Market Capitalisation & 10.88 & 10.65 & 15.24 & 6.86 & 1.63 & 0.29 & 2.65 \\
Return on Assets & 0.17 & 0.16 & 0.62 & -0.28 & 0.09 & 0.68 & 5.42 \\
Return on Capital & 19.51 & 17.2 & 93.68 & -66.79 & 14.66 & 1.20 & 7.83 \\
Employed & & & & & & & \\
Growth & 14.45 & 13.3 & 93.36 & -55.12 & 14.73 & 0.44 & 6.71 \\
Leverage & 0.20 & 0.06 & 2.07 & 0.00 & 0.30 & 2.18 & 8.96 \\
Age & 3.49 & 3.49 & 4.56 & 0.69 & 0.60 & -0.58 & 3.62 \\
Board Size & 2.33 & 2.30 & 3.25 & 1.09 & 0.27 & -0.01 & 3.18 \\
Board Independence & 0.43 & 0.44 & 0.83 & 0.00 & 0.12 & -0.26 & 3.68 \\
\hline
\end{tabular}

Source: Compiled by Author.

from -1.35 (mandatory compliance) to 2.18 (leverage) which is falling under the accepted critical values of \pm 3 for skewness and the kurtosis values ranges from 2.65 (market capitalisation) to 1.83 (return on capital employed) which again falls under the accepted critical values \pm 8 [102] however, the kurtosis value of leverage is found to be 8.96 , which is quite closer to the prescribed cut off value by [102]. Therefore, data can be concluded to be quite normal in nature.

\subsection{Model Development}

On the basis of foregoing discussion, the following model has been presented to assess the factors that could influence the Shariah compliance of the companies. The following models are employed to test H1 - H8:

$$
\begin{aligned}
& \text { Extent of Compliance (Model I) })_{i, t} \\
& =\alpha+\beta_{1} \text { LnSales }_{i, t}+\beta_{2} \text { LnTA }_{i, t}+\beta_{3} \text { LnMarket cap }_{i, t}+\beta_{4} \text { ROA }_{i, t} \\
& +\beta_{5} \text { ROCE }_{i, t}+\beta_{6} \text { Growth }_{i, t}+\beta_{7} \text { Leverage }_{i, t}+\beta_{8} \text { LnAge }_{i, t} \\
& +\beta_{9} \text { LnBoard size }_{i, t}+\beta_{10} \text { Board independence }_{i, t} \\
& +\beta_{11} \text { Nature of industry } y_{i, t}+\varepsilon_{i, t} \\
& \text { Extent of Compliance (Model II) })_{i, t} \\
& =\alpha+\beta_{1} \text { LnSales }_{i, t}+\beta_{2} \text { LnTA }_{i, t}+\beta_{3} \text { LnMarket cap }_{i, t}+\beta_{4} \text { ROA }_{i, t} \\
& +\beta_{5} \text { ROCE }_{i, t}+\beta_{6} \text { Growth }_{i, t}+\beta_{7} \text { Leverage }_{i, t}+\beta_{8} \text { LnAge }_{i, t} \\
& +\beta_{9} \text { LnBoard size }_{i, t}+\beta_{10} \text { Board independence }_{i, t} \\
& +\beta_{11} \text { Nature of industry }_{i, t}+\varepsilon_{i, t}
\end{aligned}
$$




$$
\begin{aligned}
& \text { Extent of Compliance (Model III) })_{i, t} \\
& =\alpha+\beta_{1} \text { LnSales }_{i, t}+\beta_{2} \text { LnTA }_{i, t}+\beta_{3} \text { LnMarket cap }_{i, t}+\beta_{4} \text { ROA }_{i, t} \\
& +\beta_{5} \text { ROCE }_{i, t}+\beta_{6} \text { Growth }_{i, t}+\beta_{7} \text { Leverage }_{i, t}+\beta_{8} \text { LnAge }_{i, t} \\
& +\beta_{9} \text { LnBoard size }_{i, t}+\beta_{10} \text { Board independence }_{i, t} \\
& +\beta_{11} \text { Nature of industry }{ }_{i, t}+\varepsilon_{i, t}
\end{aligned}
$$

where,

$\alpha=$ constant term, $\beta=$ slope of the explanatory variables, LnSales $=$ Net sales, LnTA = Total assets, LnMarket cap $=$ Market capitalisation, $R O A=$ Return on assets, $R O C E=$ Return on capital employed and $\mathcal{E}=$ error term.

The aforementioned regression equation is calculated for their parameters $\alpha$ and $\beta$ by employing panel regression. The unit root test (ADF) applied for all the variables evident stationarity of the panelled data. Then proceed further for estimating Breusch-Pagan Lagrange Multiplier test in order to check the pertinence of the panel data analysis over pooled data analysis.

Table 4 exhibited the results of pooled regression with respect to compliance of mandatory, voluntary and overall parameters according to Shariah principles. It is found that Net sales, Total assets, Return on assets, Growth, Leverage, Board of Independence and Construction dummy and Pharma dummy from the Industry type are significant variables which influence the compliance of mandatory parameters. Alternatively, with regard to compliance of voluntary parameters, variables among others Net sales, Market capitalisation, Growth, Director, Board of Independence and Media \& Entertainment dummy, Cement dummy, Metal dummy, IT dummy and Pharmaceutical dummy from Industry type are reported to be significant. If we look at the variables namely Market capitalisation, Net Sales, Total assets, Growth, Leverage, Director, Board of Independence and Media \& Entertainment dummy, Consumer goods dummy, Cement dummy, IT dummy, Metal dummy, and Pharma dummy from Industry type are observed to be significant subject to compliance of overall parameters. The model fit of mandatory parameters are discovered to be alright with adjusted $\mathrm{R}$ square 41.46 percent as compared to overall at 15.86 percent and voluntary parameters count as 13.75 percent, respectively. The $\mathrm{f}$ values are also reported to be significant subject to mandatory, voluntary and overall parameters. The coefficient of variables like Capital employed, Age, Industrial undertaking dummy, Financial services dummy, Fertilizer dummy, Automobile dummy, Chemical dummy, Energy dummy, Healthcare dummy and services dummy are revealed to be not significant, neither as regards to mandatory accompanied by voluntary nor overall parameters.

The foregoing results failed to notice the panel effect; therefore, they need to be taken care cautiously. For the matter of examining factors influencing the extent of Shariah compliance, a panel data regression needs to be applied. Hence, the relevance of panel regression analysis over pooled analysis has been ascertained using Breusch-Pagan Lagrange Multiplier test. 
Table 4. Pooled regression.

\begin{tabular}{|c|c|c|c|c|}
\hline Variable & Statistics & Mandatory & Voluntary & Overall \\
\hline \multirow[t]{2}{*}{ Constant } & Coefficient & $111.266^{* * *}$ & $67.117^{\star * *}$ & $70.779^{\star * \star}$ \\
\hline & Std. Error & 5.642 & 2.989 & 2.776 \\
\hline \multirow[t]{2}{*}{ Net sales } & Coefficient & $6.566^{\star * *}$ & $0.586^{\star *}$ & $1.080^{* * *}$ \\
\hline & Std. Error & 0.532 & 0.282 & 0.262 \\
\hline \multirow[t]{2}{*}{ Total Assets } & Coefficient & $-6.616^{* * *}$ & $-0.483^{\text {n.s }}$ & $-0.982^{\star *}$ \\
\hline & Std. Error & 0.913 & 0.484 & 0.449 \\
\hline \multirow[t]{2}{*}{ Market capitalisation } & Coefficient & $-0.530^{\mathrm{n} . \mathrm{s}}$ & $0.903^{* * *}$ & $0.765^{* * *}$ \\
\hline & Std. Error & 0.592 & 0.314 & 0.291 \\
\hline \multirow[t]{2}{*}{ Return on Assets } & Coefficient & $-23.599^{* * *}$ & $1.390^{\text {n.s }}$ & $-0.585^{\mathrm{n} . \mathrm{s}}$ \\
\hline & Std. Error & 7.730 & 4.094 & 3.803 \\
\hline \multirow[t]{2}{*}{ Return on Capital Employed } & Coefficient & $0.087^{\star *}$ & $-0.036^{\text {n.s }}$ & -0.026 \\
\hline & Std. Error & 0.051 & 0.027 & 0.025 \\
\hline \multirow[t]{2}{*}{ Growth } & Coefficient & $0.054^{\star *}$ & $-0.044^{\star * \star}$ & $-0.036^{\star * \star}$ \\
\hline & Std. Error & 0.025 & 0.013 & 0.013 \\
\hline \multirow[t]{2}{*}{ Leverage } & Coefficient & $-16.245^{\star \star \star}$ & $-0.040^{\text {n.s }}$ & $-1.405^{\star *}$ \\
\hline & Std. Error & 1.360 & 0.721 & 0.669 \\
\hline \multirow[t]{2}{*}{ Age } & Coefficient & $0.635^{\text {n.s }}$ & $-0.251^{\mathrm{n} . \mathrm{s}}$ & $-0.154^{\text {n.s }}$ \\
\hline & Std. Error & 0.675 & 0.358 & 0.332 \\
\hline \multirow[t]{2}{*}{ Board size } & Coefficient & $-1.930^{\mathrm{n} . \mathrm{s}}$ & $-2.692^{\star * *}$ & $-2.579^{* * *}$ \\
\hline & Std. Error & 1.575 & 0.834 & 0.775 \\
\hline \multirow[t]{2}{*}{ Board Independence } & Coefficient & $7.937^{\star * *}$ & $8.995^{\star * *}$ & $9.034^{* * *}$ \\
\hline & Std. Error & 3.027 & 1.604 & 1.489 \\
\hline \multirow[t]{2}{*}{ Industrial Manufacturing } & Coefficient & $-6.990^{\text {n.s }}$ & $-2.905^{\text {n.s }}$ & $-3.362^{\mathrm{n} . \mathrm{s}}$ \\
\hline & Std. Error & 4.391 & 2.326 & 2.160 \\
\hline \multirow[t]{2}{*}{ Consumer Goods } & Coefficient & $-7.004^{\mathrm{n} . \mathrm{s}}$ & $-3.874^{\star}$ & $-4.186^{* *}$ \\
\hline & Std. Error & 4.314 & 2.285 & 2.122 \\
\hline \multirow[t]{2}{*}{ Financial Services } & Coefficient & $-0.990^{\text {n.s }}$ & $-2.051^{\text {n.s }}$ & $-2.013^{\text {n.s }}$ \\
\hline & Std. Error & 5.801 & 3.073 & 2.854 \\
\hline \multirow[t]{2}{*}{ Fertilisers \& Pesticides } & Coefficient & $-5.354^{\mathrm{n} . \mathrm{s}}$ & $-2.612^{\text {n.s }}$ & $-2.805^{\mathrm{n} . \mathrm{s}}$ \\
\hline & Std. Error & 4.740 & 2.511 & 2.332 \\
\hline \multirow[t]{2}{*}{ Media \& Entertainment } & Coefficient & $-4.510^{\mathrm{n} . \mathrm{s}}$ & $-10.860^{\star * *}$ & $-10.234^{* * *}$ \\
\hline & Std. Error & 4.885 & 2.588 & 2.403 \\
\hline \multirow[t]{2}{*}{ automobile } & Coefficient & $-4.775^{\text {n.s }}$ & $-3.480^{\mathrm{n} . \mathrm{s}}$ & $-3.600^{*}$ \\
\hline & Std. Error & 4.407 & 2.334 & 2.168 \\
\hline \multirow[t]{2}{*}{ Cement } & Coefficient & $-4.012^{\mathrm{n} . \mathrm{s}}$ & $-5.470^{\star *}$ & $-5.359^{\star *}$ \\
\hline & Std. Error & 4.765 & 2.524 & 2.344 \\
\hline \multirow[t]{2}{*}{ Chemicals } & Coefficient & $-6.106^{\mathrm{n} . \mathrm{s}}$ & $-0.582^{\text {n.s }}$ & $-1.095^{\mathrm{n} . \mathrm{s}}$ \\
\hline & Std. Error & 4.842 & 2.565 & 2.382 \\
\hline \multirow[t]{2}{*}{ Construction } & Coefficient & $-12.495^{\star *}$ & $-1.959^{\mathrm{n} . \mathrm{s}}$ & $-2.895^{\mathrm{n} . \mathrm{s}}$ \\
\hline & Std. Error & 4.944 & 2.619 & 2.432 \\
\hline \multirow[t]{2}{*}{ Energy } & Coefficient & $-7.413^{\mathrm{n} . \mathrm{s}}$ & $-1.639^{\text {n.s }}$ & $-2.098^{\mathrm{n} . \mathrm{s}}$ \\
\hline & Std. Error & 4.508 & 2.388 & 2.218 \\
\hline \multirow[t]{2}{*}{ Healthcare } & Coefficient & $2.286^{\text {n.s }}$ & $-4.224^{\mathrm{n} . \mathrm{s}}$ & $-3.856^{\mathrm{n} . \mathrm{s}}$ \\
\hline & Std. Error & 5.937 & 3.145 & 2.921 \\
\hline
\end{tabular}


Continued

\begin{tabular}{ccccc}
\hline IT & Coefficient & $-8.352^{*}$ & $-4.551^{\star}$ & $-4.888^{* *}$ \\
& Std. Error & 4.428 & 2.346 & 2.178 \\
Metal & Coefficient & $-8.667^{*}$ & $-5.353^{* *}$ & $-5.716^{* *}$ \\
& Std. Error & 4.562 & 2.416 & 2.244 \\
& Coefficient & $-10.699^{* *}$ & $-4.731^{\star *}$ & $-5.311^{* *}$ \\
\multirow{2}{*}{ Pharmaceutical } & Std. Error & 4.360 & 2.309 & 2.145 \\
& Coefficient & $-4.632^{\text {n.s }}$ & $-2.525^{\text {n.s }}$ & $-2.764^{\text {n.s }}$ \\
& Std. Error & 4.474 & 2.370 & 2.201 \\
& Adjusted & 0.414633 & 0.137583 & 0.158648 \\
& R-Squared & & & \\
& & 24.09153 & 6.200756 & 7.147150 \\
& F-statistic & $(0.000000)$ & $(0.000000)$ & $(0.000000)$ \\
\hline
\end{tabular}

Note: ${ }^{* *} \mathrm{p}<0.01 ;{ }^{* *} \mathrm{p}<0.05 ;{ }^{*} \mathrm{p}<0.10 ; \mathrm{n} . \mathrm{s}: \mathrm{p}>0.05$; Source: Compiled by Author.

Table 5. Breusch-pagan lagrange multiplier test.

\begin{tabular}{cccc}
\hline & \multicolumn{3}{c}{ Test Hypothesis } \\
\cline { 2 - 4 } & Cross-section & Time & Both \\
\hline \multirow{2}{*}{ Model I } & 386.6998 & 0.000622 & 386.7004 \\
& $(0.0000)$ & $(0.9121)$ & $(0.0000)$ \\
\multirow{2}{*}{ Model II } & 86.53852 & 4030.081 & 4116.619 \\
& $(0.0000)$ & $(0.0000)$ & $(0.0000)$ \\
Model III & 90.67027 & 4303.096 & 4393.767 \\
& $(0.0000)$ & $(0.0000)$ & $(0.0000)$ \\
\hline
\end{tabular}

Reject the null hypothesis 5\%; Source: Compiled by Author.

Table 5 exhibits the results of Breusch-Pagan Lagrange Multiplier test which has rejected the null hypothesis of no panel effect (no variation across entities) at 5 percent significance level. Therefore, results suggested analysing the data employing panel data regression in this study.

Further, the pre-testing of model ruled out the fixed effect model due to the inclusion of sector specific dummy variable and fixed-effect model itself known as dummy model. Therefore, we proceed with the random effect model. Further, a test of homogeneity is conducted to ascertain either cross-section or time period or both effects exist in the model. The results revealed that only cross-section effect is present in case of model I consisting mandatory parameters. On the contrary, both cross-section and time period effects are existing subject to model II and model III comprising voluntary and overall parameters, respectively. Thus, cross-section (one-way variable intercept model) REM test for mandatory parameters and cross-section and time period (two-way variable intercept model) REM test has been employed to calculate the panel effects. This study consists of short panel and small sample performance might be inconsistent with the large sample estimators that make [103] or [33] variance component estimators desirable [104]. It is evident from the well-known references comprises of [33] [105] [106] [107] [108] [109] indicates that these estimators of variance compo- 
nent of random effect model are congruous but not compatible in limited samples. Thus, [103] variance component estimators are used in the study. Table 6 provides the results of panel data regression.

Table 6. Panel regression.

\begin{tabular}{|c|c|c|c|c|}
\hline Variable & Statistics & Mandatory & Voluntary & Overall \\
\hline \multirow[t]{2}{*}{ Constant } & Coefficient & $105.523^{\star * *}$ & $67.861^{\star * *}$ & $71.444^{\star * *}$ \\
\hline & Std. Error & 11.930 & 4.443 & 4.268 \\
\hline \multirow[t]{2}{*}{ Net sales } & Coefficient & $4.729^{* * *}$ & $0.726^{* *}$ & $1.159^{* * *}$ \\
\hline & Std. Error & 0.887 & 0.350 & 0.330 \\
\hline \multirow[t]{2}{*}{ Total Assets } & Coefficient & $-5.352^{* * *}$ & -0.175 & -0.696 \\
\hline & Std. Error & 1.267 & 0.533 & 0.499 \\
\hline \multirow[t]{2}{*}{ Market capitalisation } & Coefficient & $0.564^{\mathrm{n} . \mathrm{s}}$ & $-0.286^{\mathrm{n} . \mathrm{s}}$ & $-0.295^{\mathrm{n} . \mathrm{s}}$ \\
\hline & Std. Error & 0.609 & 0.320 & 0.294 \\
\hline \multirow{2}{*}{ Return on Assets } & Coefficient & $-11.399^{\mathrm{n} . \mathrm{s}}$ & $6.071^{\text {n.s }}$ & $4.423^{\mathrm{n} . \mathrm{s}}$ \\
\hline & Std. Error & 7.051 & 3.278 & 2.992 \\
\hline \multirow[t]{2}{*}{ Return on Capital Employed } & Coefficient & $0.034^{\mathrm{n} . \mathrm{s}}$ & $-0.021^{\mathrm{n} . \mathrm{s}}$ & $-0.015^{\text {n.s }}$ \\
\hline & Std. Error & 0.051 & 0.023 & 0.021 \\
\hline \multirow[t]{2}{*}{ Growth } & Coefficient & $0.044^{* *}$ & $-0.008^{\mathrm{n} . \mathrm{s}}$ & $-0.002^{\mathrm{n} . \mathrm{s}}$ \\
\hline & Std. Error & 0.021 & 0.010 & 0.009 \\
\hline \multirow[t]{2}{*}{ Leverage } & Coefficient & $-17.886^{* * *}$ & $0.240^{\text {n.s }}$ & $-1.232^{*}$ \\
\hline & Std. Error & 1.579 & 0.696 & 0.642 \\
\hline \multirow[t]{2}{*}{ Age } & Coefficient & $2.273^{\text {n.s }}$ & $-0.599^{\text {n.s }}$ & $-0.414^{\mathrm{n} . \mathrm{s}}$ \\
\hline & Std. Error & 1.478 & 0.526 & 0.507 \\
\hline \multirow[t]{2}{*}{ Board size } & Coefficient & $-3.316^{*}$ & $0.302^{\text {n.s }}$ & $0.167^{\text {n.s }}$ \\
\hline & Std. Error & 1.913 & 0.865 & 0.800 \\
\hline \multirow[t]{2}{*}{ Board Independence } & Coefficient & $0.694^{\mathrm{n} . \mathrm{s}}$ & $3.378^{\star *}$ & $3.322^{* *}$ \\
\hline & Std. Error & 2.983 & 1.412 & 1.293 \\
\hline \multirow[t]{2}{*}{ Industrial Manufacturing } & Coefficient & $-7.201^{\mathrm{n} . \mathrm{s}}$ & $-0.503^{\text {n.s }}$ & $-1.038^{\text {n.s }}$ \\
\hline & Std. Error & 10.199 & 3.456 & 3.344 \\
\hline \multirow[t]{2}{*}{ Consumer Goods } & Coefficient & $-6.967^{\mathrm{n} . \mathrm{s}}$ & $-1.235^{\mathrm{n} . \mathrm{s}}$ & $-1.634^{\mathrm{n} . \mathrm{s}}$ \\
\hline & Std. Error & 10.127 & 3.419 & 3.311 \\
\hline \multirow[t]{2}{*}{ Financial Services } & Coefficient & $-3.533^{\text {n.s }}$ & $-0.252^{\text {n.s }}$ & $-0.398^{\text {n.s }}$ \\
\hline & Std. Error & 13.892 & 4.655 & 4.512 \\
\hline \multirow[t]{2}{*}{ Fertilisers \& Pesticides } & Coefficient & $-5.882^{\mathrm{n} . s}$ & $-0.425^{\mathrm{n} . \mathrm{s}}$ & $-0.697^{\text {n.s }}$ \\
\hline & Std. Error & 11.136 & 3.767 & 3.648 \\
\hline \multirow[t]{2}{*}{ Media \& Entertainment } & Coefficient & $-2.879^{\text {n.s }}$ & $-9.309^{* *}$ & $-8.617^{\star *}$ \\
\hline & Std. Error & 11.436 & 3.856 & 3.733 \\
\hline \multirow[t]{2}{*}{ automobile } & Coefficient & $-4.753^{\mathrm{n} . \mathrm{s}}$ & $-0.906^{\mathrm{n} . \mathrm{s}}$ & $-1.100^{\mathrm{n} . \mathrm{s}}$ \\
\hline & Std. Error & 10.366 & 3.504 & 3.394 \\
\hline \multirow[t]{2}{*}{ Cement } & Coefficient & $-4.295^{\mathrm{n} . \mathrm{s}}$ & $-2.118^{\text {n.s }}$ & $-2.095^{\text {n.s }}$ \\
\hline & Std. Error & 11.169 & 3.788 & 3.668 \\
\hline \multirow[t]{2}{*}{ Chemicals } & Coefficient & $-6.571^{\mathrm{n} . s}$ & $0.789^{\text {n.s }}$ & $0.231^{\mathrm{n} . \mathrm{s}}$ \\
\hline & Std. Error & 11.475 & 3.865 & 3.744 \\
\hline \multirow[t]{2}{*}{ Construction } & Coefficient & $-15.003^{\mathrm{n} . \mathrm{s}}$ & $0.746^{\mathrm{n} . \mathrm{s}}$ & $-0.348^{\mathrm{n} . \mathrm{s}}$ \\
\hline & Std. Error & 11.543 & 3.905 & 3.780 \\
\hline
\end{tabular}


Continued

\begin{tabular}{|c|c|c|c|c|}
\hline \multirow[t]{2}{*}{ Energy } & Coefficient & $-8.851^{\text {n.s }}$ & $0.946^{\text {n.s }}$ & $0.410^{\text {n.s }}$ \\
\hline & Std. Error & 10.516 & 3.576 & 3.461 \\
\hline \multirow[t]{2}{*}{ Healthcare } & Coefficient & $3.251^{\text {n.s }}$ & $-1.562^{\mathrm{n} . \mathrm{s}}$ & $-1.196^{\mathrm{n} . \mathrm{s}}$ \\
\hline & Std. Error & 13.990 & 4.713 & 4.565 \\
\hline \multirow[t]{2}{*}{ IT } & Coefficient & $-8.876^{\mathrm{n} . s}$ & $-1.826^{\mathrm{n} . \mathrm{s}}$ & $-2.251^{\mathrm{n} . s}$ \\
\hline & Std. Error & 10.356 & 3.504 & 3.392 \\
\hline \multirow[t]{2}{*}{ Metal } & Coefficient & $-11.881^{\mathrm{n} . \mathrm{s}}$ & $-2.628^{\mathrm{n} . \mathrm{s}}$ & $-3.145^{\mathrm{n} . \mathrm{s}}$ \\
\hline & Std. Error & 10.615 & 3.616 & 3.499 \\
\hline \multirow[t]{2}{*}{ Pharmaceutical } & Coefficient & $-12.160^{\mathrm{n} . \mathrm{s}}$ & $-1.363^{\mathrm{n} . \mathrm{s}}$ & $-2.112^{\mathrm{n} . s}$ \\
\hline & Std. Error & 10.219 & 3.461 & 3.351 \\
\hline \multirow[t]{12}{*}{ Services } & Coefficient & $-5.130^{\mathrm{n} . \mathrm{s}}$ & $-0.421^{\mathrm{n} . \mathrm{s}}$ & $-0.711^{\mathrm{n} . s}$ \\
\hline & Std. Error & 10.525 & 3.552 & 3.438 \\
\hline & $\begin{array}{c}\text { t-Statistic } \\
\text { Prob. }\end{array}$ & & & \\
\hline & Cross-Section & $\{9.332386\}$ & $\{2.985032\}$ & $\{2.951882\}$ \\
\hline & Random & {$[0.6294]$} & {$[0.2768]$} & {$[0.3034]$} \\
\hline & Perind Pandom & & $\{3.414900\}$ & $\{3.217414\}$ \\
\hline & Period Kandom & - & {$[0.3623]$} & {$[0.3605]$} \\
\hline & Idiosyncratic & $\{7.161847\}$ & $\{3.408263\}$ & $\{3.106601\}$ \\
\hline & Random & {$[0.3706]$} & [0.3609] & {$[0.3361]$} \\
\hline & $\begin{array}{l}\text { Adjusted } \\
\text { R-Squared }\end{array}$ & 0.239735 & 0.030439 & 0.047920 \\
\hline & F-statistic & 11.27977 & 2.023455 & 2.640805 \\
\hline & F-statistic & $(0.000000)$ & $(0.002294)$ & $(0.000026)$ \\
\hline
\end{tabular}

Note: ${ }^{* * *} \mathrm{p}<0.01 ;{ }^{* *} \mathrm{p}<0.05 ;{ }^{*} \mathrm{p}<0.10 ;$ n.s: $\mathrm{p}>0.05\{\}$ denoted S.D; [] denotes Rho. Source: Author Compilation.

Table 6 presents the empirical results of panel data regression analysis. This study examined whether the factor variables chosen could influence the extent of Shariah compliance or not. The dependent variables such as mandatory index, voluntary index and overall index are considered for the first, second and third panel data regression model, respectively. The empirical results of the analysis for the model I show that net sales (0.00) and growth (0.036) are found to be statistically significant. Subsequently, total assets are having negative coefficient $(-5.352)$ with the corresponding $\mathrm{p}$ value $(0.00)$ followed by leverage with negative coefficient $(-17.886)$ and significant $p$ value $(0.00)$. On the other hand, market capitalisation, profitability, age of the company, board size, board independence and nature of industry were not observed to be statistically significant. Hence, it can be stated that net sales and growth influence the compliance of Shariah principles of the different companies. On the contrary, results showed that increase in total assets and leverage would lower the compliance of Shariah principles by the companies. The findings pertaining to effects of cross-section reported the estimates of $\sigma_{\mu}$ (cross-section) is 9.33 and $\sigma_{v}$ (idiosyncratic random) is 7.16. It implies that the variance of the cross-section effects is $62 \%$ of the total variance, while the variance of the time effects is not there and the 
variance of the remainder effects is $37.9 \%$ of the total variance.

Similarly, the results of analysis with regard to model II on the basis of sub-section as voluntary index reports that net sales $(0.038)$ and board Independence $(0.017)$ are the only significant variables found, than others in the model. But the coefficient of media \& entertainment industry is negative (-9.309) and associated $p$ value (0.016). Furthermore, the estimates of $\sigma_{\mu}$ (cross-section) are observed to be 2.9 and the estimate of $\sigma_{\lambda}$ (time period) is 3.4 and the estimate of $\sigma_{v}$ (idiosyncratic random) is 3.4. It signifies that the variance of the cross-section effects is $27.6 \%$ of the total variance, whereas the variance of the time effects is $36.2 \%$ and the $36.1 \%$ comprises of the remainder effects variance out of the total variance.

Followed by the empirical results of previous one, model III such as overall index indicates that net sales (0.001) and board independence (0.010) are observed to be statistically significant. Whereas, media \& entertainment industry is ascertained with negative coefficient $(-8.617)$ and significant $p$ value $(0.021)$ which demonstrated an inverse relationship. These results are also consistent with the findings of second model namely voluntary index. The figure of $\sigma_{\mu}$ (cross-section) is found to be $2.9 \%$ and $\sigma_{\lambda}$ (time period) is 3.2 and the figure of $\sigma_{v}$ (idiosyncratic random) is 3.1. It indicates that the variation in the cross-section effects is $30 \%$ followed by time effects is $36 \%$ of the total variance, however the variance of the remainder effects is $33.6 \%$ from the total variance. The findings of the present study are corroborated by the results of some previous studies that the firm size as measured by their total assets significantly influences the extent of Islamic social reporting [44] [46] [110]-[120]. Likewise, [20] [121] established no significant relationship between leverage and the extent of voluntary disclosure. Nevertheless, other studies did not observe a significant relationship between leverage and disclosure [50] [51] [122] [123].

\section{Concluding Remarks}

Islamic finance offers investment opportunities for the investors similar to conventional counterparts. However, Islamic finance differs with regard to compliance of Shariah principles from mainstream counterparts. The extent of compliance of Shariah principles could vary from one company to another company, nevertheless the firm-specific attributes tend to influence Shariah compliance by the companies.

Therefore, an attempt has been made to evaluate the relationship between company specific attributes and variation in Shariah compliance of the companies. In the last few decades there are several studies examining relationship between corporate specific attributes and the level of disclosure have been increasingly witnessed, overlooking the disclosure of Shariah compliance. Owing to this fact, the present study is motivated to examine the various factors chosen could influence the Shariah compliance of the companies. The result of this study reveals that the Shariah compliance of the companies is influenced by firm size 
measured by net sales in all the three models. Hence, it appears that large company has a tendency to share more information in order to reduce the agency cost [46]. Since large companies comes in the focus of public attention which makes them comply more with the Shariah principles. Furthermore, board independence is found to be significant in the voluntary as well as overall model. It implies that the number of independent directors has a positive and noteworthy effect on Shariah compliance by the companies. However, the effect of media \& entertainment industry is observed to be significant but with negative coefficient indicates that as many as companies in this industry, lower would be the compliance of Shariah principles. The reason could be variations in the functioning of companies from one industry to another. Moreover, the results also indicated a significant association between growth and Shariah compliance of the company in the mandatory model. This suggested that the companies with higher growth rate would conform the Shariah principles. Conversely, total assets and leverage having negative coefficient with the associated significant $p$ value showed that the Shariah compliance is expected to come down with the increase in total assets and leverage of the company in the model I.

From the above discussion it is evident that the companies with large size and higher growth rate have significant mandatory compliance. Whereas, firm size measuring with net sales and board independence has significant voluntary, subsequently overall compliance. The findings of this study are having significant implications as it provided information on firm specific characteristics for the investors who are looking for investment in Shariah compliant companies. In this way, investor would be able to keep an eye on their investment. These results may also be advantageous to the regulators in making decisions. Future research should be conducted to examine the other factors which might have been overlooked to consider in this study and could influence the Shariah compliance of the companies.

\section{Conflicts of Interest}

The authors declare no conflicts of interest regarding the publication of this paper.

\section{References}

[1] Ho, C.S. (2015) International Comparison of Shari'ah Compliance Screening Standards. International Journal of Islamic and Middle Eastern Finance and Management, 8, 222-245. https://doi.org/10.1108/IMEFM-07-2014-0065

[2] Derigs, U. and Marzban, S. (2009) New Strategies and a New Paradigm for Shariah-Compliant Portfolio Optimization. Journal of Banking \& Finance, 33, 1166-1176. https://doi.org/10.1016/j.jbankfin.2008.12.011

[3] Naughton, S. and Naughton, T. (2000) Religion, Ethics and Stock Trading: The Case of an Islamic Equities Market. Journal of Business Ethics, 23, 145-159. https://doi.org/10.1023/A:1006161616855

[4] Htay, S.N.N., Abedeen, Z. and Salman, S.A. (2013) Towards Standardization of 
Shari'ah Screening Norms and Practices. International Journal of Humanities and Social Science Invention, 2, 23-30.

[5] Mian, K.M. (2008) Shariah Screening and Islamic Equity Indexes. Islamic Finance: A Practical Guide, 51, 25-39.

[6] Zaher, T.S. and Kabir Hassan, M. (2001) A Comparative Literature Survey of Islamic Finance and Banking. Financial Markets, Institutions \& Instruments, 10, 155-199. https://doi.org/10.1111/1468-0416.00044

[7] Akram Laldin, M. (2008) Islamic Financial System: The Malaysian Experience and the Way Forward. Humanomics, 24, 217-238.

https://doi.org/10.1108/08288660810899377

[8] Dusuki, A.W. (2008) Fiqh Issues in Short Selling as Implemented in the Islamic Capital Market in Malaysia. Islamic Economics, 21, 63-78. https://doi.org/10.4197/islec.21-2.3

[9] Wilson, R. (2003) Regulatory Challenges Posed by Islamic Capital Market Products and Services. Centre for Middle Eastern and Islamic Studies, University of Durham, Durham.

[10] Dusuki, A.W. (2010) Do Equity-Based Sukuk Structures in Islamic Capital Markets Manifest the Objectives of Shariah? Journal of Financial Services Marketing, 15, 203-214. https://doi.org/10.1057/fsm.2010.17

[11] Haqqi, A.R.A. (2014) Shariah Governance in Islamic Financial Institution: An Appraisal. US-China Law Review $V, 11,112$.

[12] Hamza, H. (2013) Sharia Governance in Islamic Banks: Effectiveness and Supervision Model. International Journal of Islamic and Middle Eastern Finance and Management, 6, 226-237. https://doi.org/10.1108/IMEFM-02-2013-0021

[13] Ashraf, D. and Khawaja, M. (2016) Does the Shariah Screening Process Matter? Evidence from Shariah Compliant Portfolios. Journal of Economic Behavior \& Organization, 132, 77-92. https://doi.org/10.1016/j.jebo.2016.10.003

[14] Soke Fun Ho, C., Masood, O., Abdul Rehman, A. and Bellalah, M. (2012) Syariah Accounting and Compliant Screening Practices. Qualitative Research in Financial Markets, 4, 240-254. https://doi.org/10.1108/17554171211252556

[15] DeLorenzo, Y.T. (2000) Shariah Supervision of Islamic Mutual Funds. 4th Annual Harvard Forum on Islamic Finance.

[16] Ashraf, D. and Mohammad, N. (2014) Matching Perception with the Reality-Performance of Islamic Equity Investments. Pacific-Basin Finance Journal, 28, 175-189. https://doi.org/10.1016/j.pacfin.2013.12.005

[17] Zandi, G., Razak, D.A. and Hussin, N.H. (2014) Stock Market Screening: An Analogical Study on Conventional and Shariah-Compliant Stock Markets. Asian Social Science, 10, 270-279. https://doi.org/10.5539/ass.v10n22p270

[18] Cerf, A.R. (1961) Corporate Reporting and Investment Decision. University of California Press, Berkeley, CA.

[19] Patton, J. and Zelenka, I. (1997) An Empirical Analysis of the Determinants of the Extent of Disclosure in Annual Reports of Joint Stock Companies in the Czech Republic. The European Accounting Review, 6, 605-626.

https://doi.org/10.1080/09638189700000003

[20] Wallace, R.S.O., Naser, K. and Mora, A. (1994) The Relationship between the Comprehensiveness of Corporate Annual Reports and Firm Specific Characteristics in Spain. Accounting and Business Research, 25, 41-53.

https://doi.org/10.1080/00014788.1994.9729927 
[21] Tai, B.Y.K., Au-Yeung, P.K., Kwok, M.C. M. and Lau, L.C.W. (1990) Non-Compliance with Disclosure Requirements in Financial Statements: The Case of Hong Kong Companies. The International Journal of Accounting, 25, 99-112.

[22] Cooke, T.E. (1989) Disclosure in the Corporate Annual Reports of Swedish Companies. Accounting, and Business Research, 19, 113-124. https://doi.org/10.1080/00014788.1989.9728841

[23] Wallace, R.S.O. (1988) Corporate Financial Reporting in Nigeria. Accounting and Business Research, 18, 352-362. https://doi.org/10.1080/00014788.1988.9729382

[24] Firth, M.A. (1979) The Impact of Size, Stock Market Listing and Auditors on Voluntary Disclosure in Corporate Annual Reports. Accounting and Business Research, 9, 273-280. https://doi.org/10.1080/00014788.1979.9729168

[25] Buzby, S.L. (1975) Company Size, Listed Versus Unlisted Stocks, and the Extent of Financial Disclosure. Journal of Accounting Research, 13, 16-37. https://doi.org/10.2307/2490647

[26] Singhvi, S.S. and Desai, H.B. (1971) An Empirical Analysis of the Quality of Corporate Financial Disclosure. Accounting Review, 46, 129-138.

[27] Maali, B., Casson, P. and Napier, C. (2006) Social Reporting by Islamic Banks. Abacus, 42, 266-289. https://doi.org/10.1111/j.1467-6281.2006.00200.x

[28] Gray, R., Kouhy, R. and Lavers, S. (1995) Corporate Social and Environmental Reporting: A Review of the Literature and a Longitudinal Study of UK Disclosure. Accounting, Auditing and Accountability Journal, 8, 47-77. https://doi.org/10.1108/09513579510146996

[29] Zeghal, D. and Ahmed, S.A. (1990) Comparison of Social Responsibility Information Disclosure Media Used by Canadian Firms. Accounting, Auditing and Accountability Journal, 3, 38-53. https://doi.org/10.1108/09513579010136343

[30] Guthrie, J.E. and Parker, L.D. (1989) Corporate Social Reporting: A Rebuttal of Legitimacy Theory. Accounting and Business Research, 19, 343-352. https://doi.org/10.1080/00014788.1989.9728863

[31] Muwazir, M.R., Muhamad, R. and Noordin, K. (2006) Corporate Social Responsibility Disclosure: A Tawhidic Approach. Journal Syariah, 14, 125-142.

[32] Haniffa, R. and Hudaib, M. (2007) Exploring the Ethical Identity of Islamic Banks via Communication in Annual Reports. Journal of Business Ethics, 76, 97-116. https://doi.org/10.1007/s10551-006-9272-5

[33] Wallace, T.D. and Hussain, A. (1969) The Use of Error Components Models in Combining Cross Sections with Times Series Data. Econometrica, 37, 55-72. https://doi.org/10.2307/1909205

[34] Inchausti, B.G. (1997) The Influence of Company Characteristics and Accounting Regulation on Information Disclosed by Spanish Firms. European Accounting Review, 6, 45-68. https://doi.org/10.1080/096381897336863

[35] Owusu-Ansah, S. (1998) The Impact of Corporate Attributes on the Extent of Mandatory Disclosure and Reporting by Listed Companies in Zimbabwe. The International Journal of Accounting, 33, 605-631. https://doi.org/10.1016/S0020-7063(98)90015-2

[36] Haniffa, R.M. and Cooke, T.E. (2002) Culture, Corporate Governance and Disclosure in Malaysian Corporations. Abacus, 38, 317-349. https://doi.org/10.1111/1467-6281.00112

[37] Akhtaruddin, M. (2005) Corporate Mandatory Disclosure Practices in Bangladesh. The International Journal of Accounting, 40, 399-422. 
https://doi.org/10.1016/j.intacc.2005.09.007

[38] Clarke, D. (2006) The Independent Director in Chinese Corporate Governance. Delaware Journal of Corporate Law, 31, 125-228.

[39] Cornett, M.M., Marcus, A.J. and Tehranian, H. (2008) Corporate Governance and Pay-for-Performance: The Impact of Earnings Management. Journal of Financial Economics, 87, 357-373. https://doi.org/10.1016/j.jfineco.2007.03.003

[40] Akhtaruddin, M., Hossain, M.A., Hossain, M. and Yao, L. (2009) Corporate Governance and Voluntary Disclosure in Corporate Annual Reports of Malaysian Listed Firms. Journal of Applied Management Accounting Research, 7, 1-20.

[41] Elzahar, H. and Hussainey, K. (2012) Determinants of Narrative Risk Disclosures in UK Interim Reports. Journal of Risk Finance, 13, 133-147. https://doi.org/10.1108/15265941211203189

[42] Nur, M. and Priantinah, D. (2012) Analisis Faktor-Faktor Yang Mempengaruhi Pengungkapan Corporate Social Responsibility Di Indonesia (Studi Empiris Pada Perusahaan Berkategori High Profile Yang Listing Di BURSA EFEK INDONESIA) Jurnal Nominal, 1, 1-13.

[43] Singh, A.P. (2018) Does Size Matter?-The Effect of Size of Production Workers, Management Staff and Proprietors on Productivity. Theoretical Economics Letters, 8, 2290-2307. https://doi.org/10.4236/tel.2018.811149

[44] Ousama, A.A. and Fatima, A.H. (2006) The Determinants of Voluntary Disclosure in the Annual Reports by Shariah Approved Companies Listed on Bursa Malaysia. IIUM International Accounting Conference 3, Kuala Lumpur, Malaysia, 26-28 June 2006.

[45] Zimmerman, W.D. (1986) Positive Accounting Theory. Prentice-Hall, Englewood, NJ.

[46] Watts, R.L. and Zimmerman, J.L. (1983) Agency Problems, Auditing and the Theory of the Firm: Some Evidence. Journal of Law and Economics, 26, 613-633. https://doi.org/10.1086/467051

[47] Riyanto, B. (2001) Dasar-Dasar Pembelanjaan Perusahaan. (BPFE Yogyakarta, Ed Keempat, Cetakan Ketujuh, Yogyakarta).

[48] Raffournier, B. (1995) The Determinants of Voluntary Financial Disclosure by Swiss Listed Companies. The European Accounting Review, 4, 261-280. https://doi.org/10.1080/09638189500000016

[49] Ahmed, K. and Nicholls, D. (1994) The Impact of Non-Financial Company Characteristics on Mandatory Disclosure Compliance in Developing Countries: The Case of Bangladesh. The International Journal of Accounting, 29, 62-77.

[50] Hossain, M., Tan, L.M. and Adams, M. (1994) Voluntary Disclosure in an Emerging Capital Market: Some Empirical Evidence from Companies Listed on Kuala Lumpur Stock Exchange. The International Journal of Accounting, 29, 334-351.

[51] Malone, D., Fries, C. and Jones, T. (1993) An Empirical Investigation of the Extent of Corporate Financial Disclosure in the Oil and Gas Industry. Journal of Accounting, Auditing and Finance, 8, 249-273. https://doi.org/10.1177/0148558X9300800306

[52] Cooke, T.E. (1991) An Assessment of Voluntary Disclosure in the Annual Reports of Japanese Corporations. International Journal of Accounting, 26, 174-189.

[53] Cooke, T.E. (1993) Disclosure in Japanese Corporate Annual Reports. Journal of Business Finance \& Accounting, 20, 521-535.

https://doi.org/10.1111/j.1468-5957.1993.tb00272.x 
[54] Wagenhofer, A. (1990) The Demand for Disclosure and Actual Disclosure by firms. Paper presented at the XIII EAA Congress, Budapest.

[55] Salamon, G.L. and Dhaliwal, D.S. (1980) Company Size and Financial Disclosure Requirements with Evidence from the Segmental Reporting Issue. Journal of Business Finance and Accounting, 7, 555-568. https://doi.org/10.1111/j.1468-5957.1980.tb00221.x

[56] Kahl, A. and Belkaoui, A. (1981) Bank Annual Report Disclosure Adequacy Internationally. Accounting and Business Research, 11, 189-196. https://doi.org/10.1080/00014788.1981.9729700

[57] Chow, C.W. and Wong-Boren, A. (1987) Voluntary Financial Disclosure by Mexican Corporations. The Accounting Review, 62, 533-541.

[58] Garcia, M.A. and Monterrey, J. (1993) La revelación voluntaria en las compañias Españolas cotizadas en bolsa. Revista Española de Financiación y Contabilidad, 74, 53-70.

[59] Jaggi, B. and Low, P.W. (2000) Impact of Culture, Market Forces, and Legal System on Corporate Disclosures. International Journal of Accounting, 35, 495-519. https://doi.org/10.1016/S0020-7063(00)00076-5

[60] Xiao, J.Z., Yang, H. and Chow, C.W. (2004) The Determinants and Characteristics of Voluntary Internet-Based Disclosures by Listed Chinese Companies. Journal of Accounting and Public Policy, 23, 191-225. https://doi.org/10.1016/j.jaccpubpol.2004.04.002

[61] Elshandidy, T., Fraser, I. and Hussainey, K. (2013) Aggregated, Voluntary, and Mandatory Risk Disclosure Incentives: Evidence from UK FTSE All-Share Companies. International Review of Financial Analysis, 30, 320-333. https://doi.org/10.1016/j.irfa.2013.07.010

[62] Jensen, M.C. and Meckling, W.H. (1976) The Theory of the Firm: Managerial Behavior, Agency Costs and Ownership Structure. Journal of Financial Economics, 3, 305-360. https://doi.org/10.1016/0304-405X(76)90026-X

[63] Belkaoui, A. and Karpik, P.G. (1989) Determinants of the corporate decision to disclose social information. Accounting, Auditing and Accountability Journal, 2, 36-51. https://doi.org/10.1108/09513578910132240

[64] Retno, R.D. and Priantinah, D. (2012) Pengaruh Good Corporate Governance dan Pengungkapan Corporate Social Responsibility terhadap Nilai Perusahaan (Studi Empiris pada Perusahaan yang Terdaftar di BEI Periode 2007-2010). Jurnal Nominal, 1, 84-103.

[65] Yu, H. (2010) On the Determinants of Internet-Based Disclosure of Government Financial Information. 2010 International Conference on Management and Service Science, Wuhan, 24-26 August 2010, 1-4. https://doi.org/10.1109/ICMSS.2010.5576822

[66] Wallace, R.S.O. and Naser, K. (1995) Firm-Specific Determinants of the Comprehensiveness of Mandatory Disclosure in the Corporate Annual Reports of Firms Listed on the Stock Exchange of Hong Kong. Journal of Accounting and Public Policy, 14, 311-368. https://doi.org/10.1016/0278-4254(95)00042-9

[67] Singhvi, S.S. (1968) Corporate Disclosure through Annual Reports in the United States of America and India. The Journal of Finance, 23, 551-552. https://doi.org/10.1111/j.1540-6261.1968.tb00838.x

[68] Singh, A.P. (2017) Does FDI Promote Productivity? A Deep Dive. Indian Journal of Industrial Relations, 52, 443-456. 
[69] Lang, M. and Lundholm, R. (1993) Cross-Sectional Determinants of Analysis Rating of Corporate Disclosure. Journal of Accounting Research, 31, 246-271. https://doi.org/10.2307/2491273

[70] Roberts, R.W. (1992) Determinants of Corporate Social Responsibility Disclosure: An Application of Stakeholder Theory. Accounting, Organizations and Society, 17, 595-612. https://doi.org/10.1016/0361-3682(92)90015-K

[71] Hossain, M. and H. Hammami, H. (2009) Advances in Accounting, Incorporating Advances in International Accounting Voluntary Disclosure in the Annual Reports of an Emerging Country: The Case of Qatar. International Journal of Cardiology, 25, 255-265. https://doi.org/10.1016/j.adiac.2009.08.002

[72] Chaganti, R.S., Mahajan, V. and Sharma, S. (1985) Corporate Board Size, Composition and Corporate Failures in Retailing Industry. Journal of Management Studies, 22, 400-417. https://doi.org/10.1111/j.1467-6486.1985.tb00005.x

[73] Collier, P. and Gregory, A. (1999) Audit Committee Activity and Agency Costs. Journal of Accounting \& Public Policy, 18, 311-332. https://doi.org/10.1016/S0278-4254(99)00015-0

[74] Chen, C.J.P. and Jaggi, B. (2000) Association between Independent Non-Executive Directors, Family Control and Financial Disclosures in Hong Kong. Journal of Accounting and Public Policy, 19, 285-310. https://doi.org/10.1016/S0278-4254(00)00015-6

[75] Birnbaum, P. (1984) The Choice of Strategic Alternatives under Increasing Regulation in High Technology Industries. Academy of Management Journal, 27, 489-510.

[76] Ahmad, N. (2010) Corporate Governance Dan Profitabilitias, Pengaruhnya Terhadap Pengungkapan CSR Sosial Perusahaan. Jurnal Dinamika Akuntansi, 2, 46-55.

[77] Patelli, L. and Prencipe, A. (2007) The Relationship between Voluntary Disclosure and Independent Directors in the Presence of a Dominant Shareholder. European Accounting Review, 16, 5-33. https://doi.org/10.1080/09638180701265820

[78] Cheng, E. and Courtenay, S. (2006) Board Composition, Regulatory Regime and Voluntary Disclosure. The International Journal of Accounting, 41, 262-289. https://doi.org/10.1016/j.intacc.2006.07.001

[79] Ho, S.M.S. and Wong, K.R. (2001) A Study of the Relationship between Corporate Governance Structures and the Extent of Voluntary Disclosure. Journal of International Accounting, Auditing and Taxation, 10, 139-156. https://doi.org/10.1016/S1061-9518(01)00041-6

[80] Sprouse, R.T. (1967) Discussion of the Return to Straight-Line Depreciation: An Analysis of a Change in Accounting Method. Journal of Accounting Research, 5, 184-1 86. https://doi.org/10.1016/S1061-9518(01)00041-6

[81] Watson, A., Shrives, P. and Marston, C. (2002) Voluntary Disclosure of Accounting Ratios in the UK. The British Accounting Review, 34, 289-313. https://doi.org/10.1006/bare.2002.0213

[82] Singh, A.P. (2016) R\&D Spillovers \& Productivity Growth: Evidence from Indian Manufacturing. Indian Journal of Industrial Relations, 51, 563-579.

[83] Stanga, K.G. (1976) Disclosure in Published Annual Reports. Financial Management, 5, 42-52.

[84] Gujarati, D.N. (2009) Basic Econometrics. Tata McGraw-Hill Education, Pennsylvania, $\mathrm{PA}$.

[85] Breusch, T.S. and Pagan, A.R. (1980) The Lagrange Multiplier Test and Its Applications to Model Specification in Econometrics. The Review of Economic Studies, 47, 
239-253. https://doi.org/10.2307/2297111

[86] Honda, Y. (1985) Testing the Error Components Model with Non-Normal Disturbances. The Review of Economic Studies, 52, 681-690. https://doi.org/10.2307/2297739

[87] Moulton, B.R. and Randolph, W.C. (1989) Alternative Tests of the Error Components Model. Econometrica: Journal of the Econometric Society, 57, 685-693. https://doi.org/10.2307/1911059

[88] Baltagi, B.H., Chang, Y.J. and Li, Q. (1992) Monte Carlo Results on Several New and Existing Tests for the Error Component Model. Journal of Econometrics, 54, 95-120. https://doi.org/10.1016/0304-4076(92)90101-V

[89] Baltagi, B.H., Chang, Y. and Li, Q. (1999) Testing for Random Individual and Time Effects Using Unbalanced Panel Data. In: Fomby, T. and Carter Hill, R., Eds., Messy Data, Emerald Group Publishing Limited, Bingley, 1-20. https://doi.org/10.1108/S0731-9053(1999)0000013003

[90] Greene, W.H. (2003) Econometric Analysis. Pearson Education, Bangalore, India.

[91] Baltagi, B.H. and Li, D. (2001) LM Tests for Functional Form and Spatial Error Correlation. International Regional Science Review, 24, 194-225. https://doi.org/10.1177/016001760102400202

[92] Naser, K. and Al-Khatib, K. (2000) The Extent of Voluntary Disclosure in the Board of Directors' Statement: The Case of Jordan. Advances in International Accounting, 13, 99-118.

[93] Naser, K. (1998) Comprehensiveness of Disclosure of Non-Financial Companies: Listed on the Amman Financial Market. International Journal of Commerce and Management, 8, 88-119. https://doi.org/10.1108/eb047365

[94] Naser, K., Al-Hussaini, A., Al-Kwari, D. and Nuseibeh, R. (2006) Determinants of Corporate Social Disclosure in Developing Countries: The Case of Qatar. Advances in International Accounting, 19, 1-23. https://doi.org/10.1016/S0897-3660(06)19001-7

[95] Haniffa, R.M. and Cooke, T.E. (2005) The Impact of Culture and Governance on Corporate Social Reporting. Journal of Accounting and Public Policy, 24, 391-430. https://doi.org/10.1016/j.jaccpubpol.2005.06.001

[96] Hair Jr., J.F., Anderson, R.E., Tatham, R.L. and Black, W.C. (1995) Multivariate Data Analysis. 3rd Edition, Macmillan, New York.

[97] Kennedy, P. (1992) A Guide to Econometrics. Blackwell, Oxford.

[98] Neter, J., Wasserman, W. and Kutner, M.H. (1989) Applied Linear Regression Models. Irwin, Homewood, IL.

[99] Marquardt, D.W. (1970) Generalized Inverses, Ridge Regression, Biased Linear Estimation, and Nonlinear Estimation. Technometrics, 12, 591-256. https://doi.org/10.2307/1267205

[100] Rogerson, P.A. (2001) Statistical Methods for Geography. Sage Publishing, London. https://doi.org/10.4135/9781849209953

[101] Pan, Y. and Jackson, R.T. (2008) Ethnic Difference in the Relationship between Acute Inflammation and Serum Ferritin in US Adult Males. Epidemiology and Infection, 136, 421-431. https://doi.org/10.1017/S095026880700831X

[102] Kline, R.B. (2005) Principles and Practice of Structural Equation Modelling. 2nd Edition, Guilford Press, New York.

[103] Wansbeek, T.J. and Kapteyn, A. (1978) The Separation of Individual Variation and 
Systematic Change in the Analysis of Panel Data. Annales de Pinséé, No. 30-31, 659-680. https://doi.org/10.2307/20075307

[104] Mohammadi, T. (2012) Relative Performance of Components Variance Estimators in Random Effects Models. Iranian Journal of Economic Research, 17, 83-98.

[105] Baltagi, B.H. (1981) Pooling an Experimental Study of Alternative Testing and Estimation Procedures in Two-Way Error Components Model. Journal of Econometrics, 17, 21-49. https://doi.org/10.1016/0304-4076(81)90057-9

[106] Rao, C.R. and Kleffe, J. (1980) Estimation of Variance Components. In: Krishna kumar, P.R., Ed., Handbook of Statistics, Elsevier, North Holland, 1, 1-40.

[107] Fuller, W.A. and Battese, G.E. (1974) Estimation of Linear Models with Crossed-Error Structure. Journal of Econometrics, 2, 67-78. https://doi.org/10.1016/0304-4076(74)90030-X

[108] Swamy, P.A.V.B. and Arora, S.S. (1972) The Exact Finite Sample Properties of Estimators of Coefficients in the Error Components Regression Models. Econometrica, 40, 253-260. https://doi.org/10.2307/1909405

[109] Amemiya, T. (1971) The Estimation of Variances in Variance Components Model. International Economic Review, 12, 1-13. https://doi.org/10.2307/2525492

[110] Lestari, P. (2013) Determinants of Islamic Social Reporting in Syariah Banks: Case of Indonesia. International Journal of Business and Management Invention, 2, 28-34.

[111] Faisal, S.A. and Mishari, M.A. (2012) Dual/Joint Auditors and the Level of Compliance with International Financial Reporting Standards (IFRS-Required Disclosure) The Case of Financial Institutions in Kuwait. Journal of Economics and Administrative Sciences, 28, 109-129. https://doi.org/10.1108/10264111211248402

[112] Cynthia, A.U. (2012) Company Disclosure in Indonesia: Corporate Governance Practice, Ownership Structure, Competition and Total Assets. Asian Journal of Business and Accounting, 5, 75-108.

[113] Amar, W.B. and Zeghal, D. (2011) Board of Directors Independence and Executive Compensation Disclosure Transparency Canadian Evidence. Journal of Applied Accounting Research, 12, 43-60. https://doi.org/10.1108/09675421111130603

[114] Al Mutawaa, A. and Hewaidy, A.M. (2010) Disclosure Level and Compliance with IFRSs: An Empirical Investigation of Kuwaiti Companies. The International Business \& Economics Research Journal, 9, 1-33. https://doi.org/10.19030/iber.v9i5.566

[115] Alsaeed, K. (2005) The Association between Firm-Specific Characteristics and Disclosure: The Case of Saudi Arabia. Journal of American Academy of Business, 7, $1-310$.

[116] Awang, M., Mohamed Zain, M. and Ibrahim, M.K. (2004) An Investigation of Voluntary Disclosure in Annual Reports: The Malaysian Evidence. In: Ibrahim, M.K., Kamaruddin, K.A. and Zain, M.M., Eds., Financial Reporting in Malaysia: Some Empirical Evidence, Utusan Publications \& Distributors Sdn Bhd, Kuala Lumpur.

[117] Romlah, J., Takiah, M. and Nordin, M. (2002) An Investigation on Environmental Disclosures: Evidence from Selected Industries in Malaysia. International Journal of Business and Society, 3, 55-68.

[118] Belkaoui-Riahi, A. (2001) Level of Multinationality, Growth Opportunities and Size as Determinants of Analysts Ratings of Corporate Disclosures. American Business Review, 19, 115-220.

[119] Zain, M.M. (1999) Corporate Social Reporting in Malaysia: The Current State of the art and Future Prospects. Doctoral Dissertation, University of Sheffield, Sheffield. 
[120] Lang, M.H. and Lundholm. R.J. (1993) Cross-Sectional Determinants of Analysts Ratings of Corporate Disclosure. Journal of Accounting Research, 31, 246-271. https://doi.org/10.2307/2491273

[121] Bradbury, M.E. (1992) Voluntary Disclosure of Financial Segment Data: New Zealand Evidence. Accounting and Finance, 32, 15-26. https://doi.org/10.1111/j.1467-629X.1992.tb00174.x

[122] Carson, E. and Simnett, R. (1997) Voluntary Disclosure of Corporate Governance Practices. University of New South Wales, Sydney.

[123] McKinnon, J.L. and Dalimunthe, L. (1993) Voluntary Disclosure of Segment Information by Australian Diversified Companies. Accounting and Finance, 33, 33-50. https://doi.org/10.1111/j.1467-629X.1993.tb00192.x 